\title{
Kelch-Like Protein 42
}

National Cancer Institute

\section{Source}

National Cancer Institute. Kelch-Like Protein 42. NCI Thesaurus. Code C150042.

Kelch-like protein 42 ( $505 \mathrm{aa}, \sim 57 \mathrm{kDa}$ ) is encoded by the human KLHL42 gene. This protein is involved in microtubule dynamics and protein ubiquitination. 